\title{
Lewensstories van getroude vroue: 'n Moontlikheid tot transformasie
}

\begin{tabular}{|c|c|}
\hline \multicolumn{2}{|l|}{$\begin{array}{l}\text { Author: } \\
\text { Annelie Botha }{ }^{1}\end{array}$} \\
\hline \multicolumn{2}{|c|}{$\begin{array}{l}\text { Affiliation: } \\
{ }^{1} \text { Department of Practical } \\
\text { Theology, Faculty of } \\
\text { Theology, University of } \\
\text { Pretoria, South Africa }\end{array}$} \\
\hline \multicolumn{2}{|c|}{$\begin{array}{l}\text { Dr Annelie Botha is a } \\
\text { research associate in the } \\
\text { project 'Gender Studies and } \\
\text { Practical Theology Theory } \\
\text { Formation', directed by } \\
\text { Prof. Dr Yolanda Dreyer, } \\
\text { Department of Practical } \\
\text { Theology, Faculty of } \\
\text { Theology, University of } \\
\text { Pretoria. }\end{array}$} \\
\hline \multicolumn{2}{|c|}{$\begin{array}{l}\text { Correspondence to: } \\
\text { Annelie Botha }\end{array}$} \\
\hline \multicolumn{2}{|c|}{$\begin{array}{l}\text { Email: } \\
\text { abothaster@gmail.com }\end{array}$} \\
\hline \multicolumn{2}{|c|}{$\begin{array}{l}\text { Postal address: } \\
\text { Private Bag X20, Hatfield } \\
0028 \text {, South Africa }\end{array}$} \\
\hline \multicolumn{2}{|c|}{$\begin{array}{l}\text { Dates: } \\
\text { Received: } 08 \text { June } 2015 \\
\text { Accepted: } 14 \text { July } 2015 \\
\text { Published: } 30 \text { Sept. } 2015\end{array}$} \\
\hline \multicolumn{2}{|c|}{$\begin{array}{l}\text { How to cite this article: } \\
\text { Botha, A., 2015, } \\
\text { 'Lewensstories van getroude } \\
\text { vroue: 'n Moontlikheid } \\
\text { tot transformasie', HTS } \\
\text { Teologiese Studies/ } \\
\text { Theological Studies 71(3), } \\
\text { Art. \#3073, } 8 \text { pages. http:// } \\
\text { dx.doi.org/10.4102/hts. } \\
\text { v71i3.3073 }\end{array}$} \\
\hline \multicolumn{2}{|c|}{$\begin{array}{l}\text { Copyright: } \\
\text { (C) 2015. The Authors. } \\
\text { Licensee: AOSIS } \\
\text { OpenJournals. This work is } \\
\text { licensed under the Creative } \\
\text { Commons Attribution } \\
\text { License. }\end{array}$} \\
\hline \multicolumn{2}{|l|}{ Read online: } \\
\hline 口fra & $\begin{array}{l}\text { Scan this QR } \\
\text { code with your } \\
\text { smart phone or } \\
\text { mobile device } \\
\text { to read online. }\end{array}$ \\
\hline
\end{tabular}

Life stories of married woman: A possibility to transformation. Feminist scholarship in various disciplines has shown that women tend to internalise dominant social and religious discourse with regard to their lesser worth and value as human beings and members of society. The focal point of this article is to demonstrate how the place and role allocated to women, specifically in marital relationships, can be experienced as harmful. This article makes use of the life history research method in combination with the emancipatory analysis model of Elisabeth Schüssler Fiorenza in order to demonstrate this. Interviews were done with five women of the Netherdutch Reformed Church of Africa, a fairly conservative and traditional Afrikaans speaking South African faith community. In spite of having lived with this mindset all of their lives, the women were able to express in which ways they experienced the dominant discourse as harmful. If social and religious views devalue a certain group of people, transformation is required. In the case of women, respectfully listening to their life stories and experiences can contribute to their own healing as well as to the transformation of their social and religious environment and the practice of the church.

\section{Inleiding}

Die artikel gaan van die standpunt uit dat getroude vroue in blanke Afrikaanssprekende gemeenskappe 'n subkultuur verteenwoordig. Die vraag wat die artikel ondersoek, is of dit vir vroue moontlik is om binne hierdie subkultuur outentiek te kan lewe (kyk Sonne 1993; vgl ook die kritiese refleksie op Jürgen Habermas se ignorering van die outentisiteit van vroue in die openbare diskoers deur Meehan 1995, 2000:39-52 en veral Cohen 1995:57-90). Binne 'n religieuse en spirituele konteks is die vraag verder of dit vir vroue moontlik is om outentiek voor God te kan lewe.

Die artikel bespreek die resultate van 'n ondersoek wat met behulp van lewensstorienavorsing gedoen is. Die ondersoek bring aan die lig hoe vyf Afrikaanssprekende vroue in die konteks van die Nederduitsch Hervormde Kerk van Afrika die dominante samelewings- en religieuse diskoerse oor vroue en hulle rol binne die huwelik geïnternaliseer het. Dit toon hoe outentieke identiteitsvorming by hierdie vroue nie deur die huweliksbevestigingsformulier of die kerklike diskoers oor die huwelik bevorder is nie. Die kerklike diskoers oor die huwelik bied nie ruimte vir vroue om in hulle spiritualiteit tot selfstandige, denkende en handelende persone te ontluik nie (vgl. Schulenburg 1993:41). Waar'n samelewing se waardes en godsdienstige sienings vroue skade aandoen, is transformasie nodig (vgl. Ackermann, Draper \& Mashinini 1991:96). Transformasie kan plaasvind wanneer respekvol na die lewensstories van vroue geluister word en hulle ervaring met die nodige erns in die geloofsgemeenskap bejeën word. Dit kan daartoe bydra dat die praktyk van die kerk verander.

\section{Lewensstorienavorsing}

In lewenstorienavorsing dien die individu se narratief as 'n venster waardeur die breër sosiale werklikheid gesien en beter verstaan kan word. Lewensstorienavorsing gaan enersyds oor die individuele verhale self, en andersyds oor die interpretasie van die verhale binne die breër konteks, situasie en gemeenskap. Wanneer mense hulle lewenstories vertel, hoor 'n mens die kultuur en tradisie deur hulle praat (kyk Bertaux-Wiame 1979:30; Cole \& Knowles 2001:9-11). Hiermee word geen essensialistiese aansprake gemaak nie, byvoorbeeld dat om een individuele verhaal te verstaan, beteken om almal se verhale te verstaan. Lewensstorienavorsing gaan oor die wisselwerking tussen menslike ervaring en die sosiale konteks (kyk Cole \& Knowles 2001:10; Dhunpath 2000:545). Deur lewensstorienavorsing dra individue se ervarings daartoe by dat die breër konteks waarbinne hulle leef, beter verstaan word (Cole \& Knowles 2001:20; kyk ook Lawrence-Lightfoot 1994; Middeltone 1992). Die uitdrukking 'konteks is alles', is die slagspreuk van lewensstorienavorsing. Andersom geld dit ook dat die verstaan van 'n konteks daartoe bydra dat ' $n$ persoon se individuele narratief en kollektiewe lewe beter verstaan word. Mense druk die 
verstaan van hulle lewe uit in die vorm van narratiewe. Die verhale van individue se lewe is in die gemeenskap waarin hulle leef en waarin hulle identiteit gevorm word, ingebed (kyk Dhunpath 2000:544; Goodson 1992:241; Polkinghorne $1988: 5,7)$. Om 'n persoon se konteks te verstaan, bied ' $n$ sleutel tot die verstaan van die betrokke persoon se lewe en ervaring. Die lewensstorie illustreer hoe 'n persoon met die sosiale konteks omgaan (kyk Coles \& Knowles 2001:10-12; Geiger 1986:336; Mandelbaum 1973:177). Konteksverwante sake wat relevant is, is byvoorbeeld die familie-erfenis, rasseagtergrond, etniese en familiekultuur, die gesondheid van die familie en die individu, die sosio-ekonomiese agtergrond van die familie en die gemeenskap, religieuse invloede en praktyke, genderinvloede, opvoedkundige agtergrond, opvoedkundige instellings waar die opleiding ontvang is, politieke agtergrond en idees en persoon se waardering van haarself binne die konteks waarin sy haar bevind (Cole \& Knowles 2001:80). Kriteria waaraan lewensstorienavorsing as wetenskaplike ondersoek behoort te voldoen (kyk Cole \& Knowles 2001:125-127), is intensionaliteit, die egte teenwoordigheid (presence) van die ondersoeker, metodologiese noukeurigheid, ' $n$ holistiese benadering en effektiewe kommunikasie.

Die doel van lewensstorienavorsing is nie net om dieper insig te verkry nie, maar ook om tot transformasie by te dra. Bevindings kan die breër samelewing, geloofsgemeenskappe en beleidmakers bewus maak van onreg en skade wat mense aangedoen word wanneer hulle in die konteks waarin hulle leef nie outentiek as mense en gelowiges kan bestaan nie (Cole \& Knowles 2001:108). Bewuswording en erkenning van die skade kan tot heling en transformasie bydra. Lewensstorienavorsing het teoretiese waarde sowel as transformatiewe potensiaal. Transformatiewe potensiaal gaan daaroor dat die insigte wat uit die gesprekke met die navorsingsgenote verkry word, verder gekommunikeer word sodat hulle lewensgehalte binne hulle konteks verbeter kan word. Dit moet met ander woorde daartoe bydra dat die nodige verandering in die konteks of gemeenskap bewerkstellig word (vgl. Graham 2002:178). Lewenstorienavorsing het, net soos die emansipatoriese teologie, 'n politieke agenda, deurdat dit ten doel het om die samelewing te transformeer.

\section{Verhale van geloof en lewe}

In hierdie afdeling word die onderhoude wat met vyf vroue gevoer is, weergegee en geprosesseer. Die metodes van lewensstorienavorsing word met die emansipatoriese analisemodel van Elisabeth Schüssler Fiorenza (2006:97102) gekombineer. Schüssler Fiorenza (2006:97) begin by 'n hermeneutiek van ervaring. Die 'kyriargale strukture van dominasie' soos sy dit noem, word ondersoek om die strukture van dominansie en subordinasie waarin vroue gesosialiseer is, bloot te stel. Daarna word van 'n hermeneutiek van evaluasie gebruik gemaak, waar die ideologiese meganismes wat deur die hermeneutiek van suspisie blootgelê is, ondersoek word ten einde te bepaal hoe die dominante narratief die persoonlike narratief van vroue beïnvloed. As 'n laaste stap word 'n hermeneutiek van verandering en transformasie aangewend.

In lewensstorienavorsing is die verhouding tussen die navorser en die navorsingsvennoot belangrik, omdat dit tot die kwaliteit en egtheid bydra van wat gedeel en opgeteken word (kyk Dhunpath 2000:549; Geiger 1986:340). Die vyf navorsingsgenote is geselekteer omdat die ondersoeker reeds as pastor 'n vertrouensverhouding met hulle opgebou het. Die navorsingsgenote was vroue tussen 30 en 70 jaar (Lulu 66, Johanna 51, Ruda 47, Annetjie 37 en Kara 39). Lewensstorienavorsing kies vir 'depth over breadth' en daarom was die doel van die seleksie nie om verteenwoordigend van die samelewing te probeer wees nie, maar om deur die woorde en aksies van die navorsingsgenote hulle unieke individuele en kollektiewe ervarings te ontgin. Kennis van die konteks, invloede en die plek waar mense hulle bevind, dra daartoe by om hulle lewe en ervarings beter te verstaan. Die vyf vroue is almal Christen-gelowiges uit die Afrikaanse reformatoriese tradisie. Hulle was of is steeds getroud. Lulu se man is sewe jaar gelede oorlede; Johanna is 19 jaar gelede van haar man geskei; Ruda is geskei en het hertrou. Vier van die vyf vroue het universiteitsgrade verwerf. Uit die onderhoude is die volgende temas geïdentifiseer:

- hulle ervaring binne die huwelik

- kerk- en samelewingsdiskoerse met betrekking tot die verwagtings van die vroue binne die huwelik

- hulle verhouding met God

- hoe hulle hulleself in hulle konteks posisioneer.

Uit die vroue se narratiewe kan die kulturele diskoers geëien word, asook hoe hulle op hulle eie manier teen die kultuur en tradisie weerstand bied, asook die dominante konteks waarbinne hulle leef.

\section{Lewensstories}

\section{Ruda}

Ruda is in 1965 gebore en word op 'n plattelandse dorp in Suid-Afrika groot. Haar ouers is albei gegradueerd. Sy is die oudste van vier kinders. Na haar skoolopleiding studeer sy Aptekerswese. Aan die einde van haar vierde jaar op universiteit is sy met Piet getroud wat 'n onderwysgraad behaal het. Sy het in die Nederduitsch Hervormde Kerk van Afrika (NHKA) grootgeword. Hoe sy die geslagsrolle soos deur die destydse huweliksbevestigingsformulier van die NHKA verstaan, is dat die man die broodwinner is en die vrou onderdanig moet wees en haar man moet ondersteun. Die huwelik moet ten alle koste in stand gehou word. Reeds met die aanvang van die huwelik besef sy dat Piet nie medeverantwoordelikheid vir die instandhouding van die huweliksverhouding aanvaar nie. Telkens na gesprekke met haar ouers en veral op haar pa se aandrang, besluit sy om in die huwelik te bly. As gevolg van bankrotskap, veroorsaak deur 'n sakevennoot se bedrog, verloor hulle alles en word genoodsaak om by haar ouers te gaan woon. Die emosionele en fisiese spanning wat dit by haar man veroorsaak, lei egter tot ernstige depressie. 
Ruda en Piet het twee kinders. Sy dra die alleenverantwoordelikheid vir die versorging van die gesin, want haar man maak geen bydra nie en probeer ook nie om weer werk te kry nie. Genoodsaak deur haar omstandighede, neem Ruda 'n werksgeleentheid in Namibië aan. Daar is spanning in die huwelik omdat die rolle soos voorgeskryf in die huweliksbevestigingsformulier, nie vervul word nie. Vanweë die druk van haar pa asook die algemeen aanvaarde beginsel in die kultuurkonteks dat "n mens nie skei nie' en dat egskeiding teen God se wil ingaan, probeer sy met Piet 'n nuwe begin in Namibië maak. Nie net werk Piet steeds nie, maar hy laat ook al die werk in die huishouding en die versorging van die kinders volledig aan Ruda oor. Nadat Ruda van sy buite-egtelike verhouding verneem het, besluit sy om van haar man te skei. Van haar ouers ontvang sy geen ondersteuning nie, omdat sy 'ingaan teen wat van 'n gelowige vrou verwag word'. Dit veroorsaak 'n innerlike worsteling by haar. Sy verstaan haar voorgeskrewe rol, maar sy besef ook dat, indien sy die rol sou vervul, die gesin nie versorg sou wees nie.

In die konteks waarin sy grootgeword het, is van haar verwag om binne gemeenskap van goedere te trou. Haar man, wat as gevolg hiervan toegang tot haar bankrekening gehad het, het sonder haar medewete geld onttrek en vir homself ' $n$ neseier opgebou. Omdat hulle binne gemeenskap van goedere getroud is, moes alles met die egskeiding gelykop verdeel word. Dit het beteken dat sy haar apteek moes verkoop. Na 'n huwelik van 17 jaar het sy gevoel dat sy misluk het. Sy het nie voldoen aan wat God en die kerk van haar verwag het nie. Sy het deur die samelewing en die geloofsgemeenskap verwerp gevoel. Sy het na Suid-Afrika teruggekeer. Die hof het toesig en beheer oor haar kinders aan haar toegeken en beveel dat Piet onderhoud betaal. Dit kon hy egter nie doen nie, omdat hy steeds geen inkomste gehad het nie.

Vier jaar na die egskeiding ontmoet sy Jan, met wie sy later in die huwelik getree het. Die saamgestelde gesin is gekompliseerd en verg heelwat van haar. Ruda het intussen weer finansieel selfversorgend geword. Sy het met groot versigtigheid die stap geneem om weer te trou. Ook in haar tweede huwelik het sy, volgens hoe sy die huweliksbevestigingsformulier verstaan, haar eie beroep en werksgeleenthede ondergeskik gestel aan haar man se belange en loopbaan. Dit het die versorging van haar kinders, wat teen hierdie tyd op universiteit was, bemoeilik. Eerstens het sy self nie meer 'n inkomste gehad nie, en tweedens het haar gewese man en die kinders se pa, steeds nie sy finansiële verpligtings nakom nie. Derdens het haar tweede man, sonder om haar in die saak te ken, sy werk bedank. Ruda voel dat dit wat die kerklike tradisie oor die huwelik en die huweliksrolle leer, tot haar en haar kinders se nadeel was, en steeds is. Dit was nie vir haar as vrou moontlik om voluit te leef nie.

\section{Lulu}

Lulu is in 1946 op 'n klein plattelandse dorpie in Namibië gebore as die derde van 11 kinders. Haar pa was 'n boukontrakteur en haar ma 'n tuisteskepper. Lulu se ma was van huis uit Engelssprekend en het in Johannesburg grootgeword. Lulu se pa het met bokke geboer. Omdat daar eers later in die huwelik seuns gebore is, moes die dogters help om die diere te versorg. Lulu beskryf dit as seunswerk. Hulle moes ook hulle ma met die huiswerk help. Godsdiens was belangrik in haar ouerhuis. Lulu se pa sterf aan kanker toe sy 16 jaar oud was. Sy en haar ouer suster moes as gevolg daarvan die skool verlaat en gaan werk om met die gesin se onderhou te help. Lulu wou graag gaan studeer, maar omdat daar geen geld was nie, was dit onmoontlik. Sy wou 'n huishoudkunde-onderwyseres word. Lulu het eers in die poskantoor gewerk en later as sekretaresse vir 'n versekeringsmaatskappy. Sy het haar man ontmoet toe sy 17 was en is ses jaar later met hom getroud. Haar man, Neels, was nie 'n kerkganger toe sy hom ontmoet het nie. Onder haar invloed het hy egter begin om kerk toe te gaan.

In haar ouerhuis is sy godsdienstig opgevoed en het 'n verdieping in haar geloof ervaar na haar pa se dood. Sy beleef daagliks hoe daar vir haar en haar gesin gesorg word en hoe daar uitkoms gegee word wanneer hulle nood het. Lulu en haar man het saam hard op die plaas gewerk. Oor geslagsrolle sê sy die volgende:

'Daar was nie iets soos dit doen ' $n$ man en dit doen ' $n$ vrou nie. 'n Mens doen wat nodig is, wat jy moet doen. Ek het dikwels self die vragmotor bestuur, net die dooie vrag, nie die lewende vrag nie.'

Hulle was $100 \mathrm{~km}$ van die naaste dorp af en kon net al om die drie maande dorp toe gegaan. Hulle moes alles wat hulle nodig het, bestel sodat die vragmotor wat die melk kom haal vir hulle voorraad kon saambring. Lulu meen dat 'n mens op aarde is om vir God te lewe. Sy glo ook aan onafhanklikheid. "n Mens moenie maar toelaat dat ander alles vir jou doen nie', is hoe sy dit stel. Toe dit later finansieel beter gegaan het, het die gesin 'n plaas in SuidAfrika gekoop. Haar man moes van tyd tot tyd Suid-Afrika toe gaan om daarna om te sien. Dan het sy alleen op die plaas in Namibië geboer. Sy het dit geniet om selfstandig te boer. Sy stel dit soos volg:

'Ons het baie na mekaar verlang, maar dit was lekker dat' $n$ mens jouself bietjie kan bewys as vrou, kan wys jy kan boer, want dit is nie net ' $n$ man wat kan boer nie. Ek het myself bewys.'

Hoewel haar man hoofsaaklik die finansies bestuur het, het Lulu dit behartig as hy in Suid-Afrika was. Ook dit het haar menswaardig laat voel.

Toe haar man in 2007 aan longkanker oorlede is, was dit haar verhouding met God wat Lulu staande gehou het. Sy het na die dorp verhuis, maar aangehou boer. Sy beskryf haar huwelik as "n vriend en vriendin verhouding'. Hulle kon vir ure met mekaar oor die boerdery, hulle lewe, die lewe in die algemeen en oor geloof praat. Hulle het graag gesprekke oor die Bybel gevoer. Op die dorp waar sy woon, versorg Lulu haar moeder van 93 en doen ook barmhartigheidswerk. Sy dien in die gemeente waar sy as kerkraadslid inskakel. Sy het opgehou boer. Sy is tevrede 
dat sy haarself as boer bewys het, maar nou rustiger kan lewe. Volgens haar het die swaarkry in haar lewe van haar 'n beter mens en gelowige gemaak.

\section{Johanna}

Johanna is in 1961 gebore en het op 'n klein plattelandse dorp grootgeword as die jongste van drie kinders en die enigste dogter. Haar pa was 'n spoorwegwerker sonder matriek en haar ma'n tuisteskepper. Haar ouers was getroue kerkgangers en haar ma was die enigste kategeet in die klein gemeente. Gedurende haar hoërskoolloopbaan het hulle dikwels verhuis. Sy meen dat mense deur hulle ouers en hulle posisie in die gesin gevorm word. Sy is die enigste een van die kinders wat universiteit toe is. Haar ouers het haar hierin ondersteun. Sy behaal onder andere die MBAgraad. Johanna beskryf die ouerhuis en samelewing waarin sy grootgeword het as patriargaal. Die geslagsrolle in haar ouers se huwelik, was tradisioneel. Sy stel dit soos volg: 'Pa se woord was wet. My pa se rol was die van broodwinner en my ma se taak was die huishouding en bestuur van die finansies.' Haar ma moes sorg dat die uitgawes binne die familie se finansiële vermoë bly. Sy was die een wat besluite geneem het ten opsigte van wat gekoop kan word en wat nie, wat nodig is en wat nie.

Johanna is op 21 getroud. Sy en haar man het hulle in Pretoria gevestig. Haar man se ma het 'n sterker persoonlikheid gehad as sy pa. Sy het buitenshuis gewerk en geld verdien. Sy het die besluite in die huis geneem. Johanna en haar man het albei vir die staat gewerk. Omdat hy geen formele kwalifikasies gehad het nie, is sy bo hom bevorder. Aanvanklik het mans meer as vroue in die staatsdiens verdien. Haar man het sonder 'n universiteitsgraad meer verdien as sy wat gegradueerd was. Later het sy hom egter verbygegaan. Hy het dikwels negatiewe dinge oor gegradueerde mense gesê. Na 12 jaar het haar man 'n buite-egtelike verhouding aangegaan en Johanna het van hom geskei. Sy het op 'n ander dorp begin werk. Sy interpreteer haar man se buite-egtelike verhouding as dat hy dit aangeknoop het in 'n tyd toe sy gereeld laat moes werk, nie genoeg aandag aan hom gegee het en nie aan sy behoeftes voldoen het nie. Haar gevoel van eiewaarde het in die proses 'n knou gekry. Sy interpreteer die mislukking van haar huwelik soos volg:

'Die duiwel gaan juis na mense toe wat gelukkig getroud is, dink ek, hy het mos nou geen doel om 'n ongelukkige huwelik op te mors nie, hy mors graag gelukkige huwelike op.'

Sy verduidelik hoe sy God verstaan:

'Ek glo in die Here, soos 'n kind in die Here glo, ek analiseer nie godsdiens nie, ek probeer nie, want as ek begin analiseer en te veel en te diep wil delf, raak ek verward. Maar ek glo ook dat die duiwel definitief ' $n$ invloed op mense se lewens het, dat die duiwel wel listig is, en mense verkeerde dinge kan laat doen. Die duiwel kan jou versoek ... Dit is ook een van die dinge (ek weet nie of dit reg is nie) wat ek glo, dat die Here ook lelike dinge met mens laat gebeur om mens te brei. Hy mak my gereed vir sy koninkryk. Ek dink die Here het ook my deur 'n egskeiding laat gaan sodat ek ander mense kan help. Want ek sou nie empatie gehad het in my werk as ek nie hierdeur gegaan het nie.'
Ten tye van haar egskeiding het Johanna Christelike lektuur gelees en ervaar dat sy daardeur in haar geloof bemoedig en versterk is. Sy beskou dit as sonde om te skei. Sy glo egter wel dat God haar vergewe het, maar dat sy as geskeide vrou nie weer mag trou nie, omdat dit, letterlik volgens die Bybel sal veroorsaak dat die man met wie sy trou, ook egbreuk pleeg.

\section{Annetjie}

Annetjie is in 1975 op die platteland gebore. Sy het net een broer. Haar pa was 'n boer en haar ma 'n onderwyseres. In haar ouerhuis was die rolverdeling dat die vrou die huishouding en kinderversorging behartig het, en die man die finansies en besluitneming. Sy meen dat, as haar pa te sterwe sou kom, haar ma nie haar eie finansiële sake sal kan bestuur nie. Haar ma het die kinders egter grootgemaak met die boodskap dat hulle op alles voorbereid moet wees. Sy stel dit soos volg:

'My ma het altyd gesê mens moet vir jouself kan sorg. Jy moenie van 'n man afhanklik wees nie. Dit is nie te sê dat jou man altyd daar sal wees nie.'

Wat die huwelik betref, het haar ma gemeen 'n goeie verhouding en wedersydse respek is die kern. Die kinders is geleer dat niemand volmaak is nie. Daarom moet hulle seker wees dat hulle met die ander se gebreke sal kan saamleef voordat hulle trou. Sy het gewaarsku dat 'n mens nie moet dink dat jy die ander persoon gaan verander nie.

Die kinders is aangemoedig om verder te studeer. Annetjie is gegradueerd. Sy trou met Henrie, 'n mediese dokter op die platteland in Namibië. Annetjie begin 'n eie oogkundige praktyk op die dorp. Na die geboorte van hulle twee kinders probeer sy haar verpligtinge verminder na halfdag, maar dit is nie altyd moontlik nie. Sy beskryf die rolverdeling in haar huwelik soos volg:

'Ek moet nog maar steeds die tradisionele pligte van 'n vrou uitvoer: kos maak, kinders versorg, aankope doen vir die huis. Ek is wel ook 'n broodwinner. Ek sal nie sê hy help eintlik met die huishouding nie. Hy sal so nou en dan kos maak, maar hy help nie eintlik met die kinders nie.'

Haar man se gesin van oorsprong beskryf sy soos volg: 'Sy ma is 'n baie sterk vrou. Sy ma het baie dinge gedoen, wat sy pa volgens my eintlik moes doen.' Haar man verwag dat sy heeltemal onafhanklik van hom moet funksioneer net soos sy ma. Dit is egter nie vir Annetjie aanvaarbaar nie. Hy verwag van haar om sowel haar buitenshuise werk en 'die vrou se werk' in die huis te doen, terwyl hy algehele vryheid kan geniet. Wat hulle interaksie as egpaar betref, meen Annetjie dat die kommunikasie nie altyd goed is nie. Hulle praat dinge nie uit nie. Ten spyte van die verskillende verwagtings wat hulle ten opsigte van die rolle in hulle huwelik het, meen sy dat sy gelukkig is omdat hulle goed oor die weg kom. Daar is nie twis en rusie in hulle huwelik nie. Wedersydse respek in die huwelik is vir haar baie belangrik en ook om vir die gemeenskap aanvaarbaar te wees. 
Sy ervaar God as teenwoordig in haar lewe en as haar beskerming. 'n Gelowige se taak en roeping is om God te dien en volgens God se wil te lewe. Sy ervaar God se leiding en glo dat selfs moeilike en slegte dinge in die lewe goed sal uitwerk. Die lewe bestaan uit goeie en moeilike dinge. God laat nie slegte dinge met mense gebeur om hulle te straf nie. Sy glo dat God engele stuur om oor haar en haar gesin te waak en dat die Tien Gebooie die hoeksteen en grondslag van 'n gelowige se lewe behoort te wees. Sy kan haar nie 'n lewe sonder God voorstel nie.

\section{Kara}

Kara is in 1973 op die platteland gebore as die middelste van drie dogters. Vanweë haar pa se werksomstandighede het hulle dikwels verhuis. Tydens haar laerskoolloopbaan was sy in 12 skole. Sy beskou dit is die rede waarom sy moeilik vriende maak en mense nie maklik vertrou nie. Op 12 jaar het die gesin na 'n klein dorpie in Namibië verhuis. Van die klein skool op die platteland na die hoërskool in die hoofstad was 'n groot verskil en aanpassing vir haar. Haar ouers was gereelde kerkgangers, die kinders het die kategese bygewoon en hulle het as gesin by die kerk ingeskakel. Haar ouers se verhouding was moeilik. Daar was heelwat onenigheid en misverstande. Haar ma het voortdurend gedreig om haar pa te verlaat. Sy het haar voorgeneem dat sy dit in haar huwelik nie sou doen nie. Kara se ma het haar nooit op die huwelik voorberei nie. Toe sy op 20 verloof raak, was haar ma se woorde: 'Nou begin die harde werk, die baklei'. Kara kon nie aanvaar dat die huwelik net moeilik sal wees nie. Sy het gemeen dat daar ook aangename dinge en tye behoort te wees.

Kara het nie na die voltooiing van haar skoolloopbaan gaan studeer nie. Sy het eers as getroude vrou begin studeer. Haar man het nooit in haar pad gestaan nie. Daar is twee kinders uit hulle huwelik gebore, 'n seun en 'n dogter. Kara beskryf haar huweliksverhouding as sodanig dat sy en haar man ná aan mekaar leef en alles saam doen. Indien daar iets negatiefs insluip, kan hulle daaroor praat. Hulle het aan die begin van hulle huwelikslewe saam in die familiebesigheid gewerk. Later het hulle 'n eie besigheid gevestig. Aanvanklik het haar man lang ure gewerk en sy was baie alleen. Dit het teen haar verwagting van die huwelik ingegaan en het aanpassing geverg. Wat haar rolverwagtings in die huwelik betref, het Kara aanvanklik gemeen dat die man vir die finansies moet sorg. Later het sy aanvaar dat dit 'n gedeelde verantwoordelikheid is en sy het ook begin om buitenshuis te werk. Haar man is by kinderversorgingstake betrokke. Hulle het op 'n natuurlike manier by hulle aanvanklike idees van 'sy werk' en 'haar werk' verbygekom.

Kara beleef haar geloofsgemeenskap as behoudend en 'n konstante in haar lewe. Dit is vir haar positief. Haar geloof help haar om perspektief in die lewe te behou, veral wanneer dit moeilik gaan. Selfondersoek is vir haar belangrik. Sy vra haar af of iets is soos God dit sou wou gehad het en of wat sy doen en sê, reg is. Haar geloof beskou sy as 'n persoonlike saak. Sy praat nie veel daaroor nie. God is vir haar teenwoordig in alles wat in die lewe met 'n mens gebeur. Sy verduidelik dit soos volg:

'Ek glo dat die Here dit wat op jou pad kom, toelaat. Niks is groter as God nie. Daar sal niks gebeur wat God nie kan beheer nie, of wat nie met 'n doel op jou pad kom, wat God nie in 'n seker sin daar geplaas het nie. Dit is byvoorbeeld nie God wat ' $n$ kind laat doodgaan nie, maar God laat dit toe. Ek sien dit nie as 'n straf nie. Dit is ' $n$ ding wat op jou pad gekom het wat die Here gesê het: 'Jy is sterk genoeg om dit te hanteer, met my genade sal jy daardeur kom.' Dit is jou lewe. Jy moet daarmee cope, of dit moeilik is of lekker, of daar 'n goeie ding op jou pad kom, dit is hoe jou lewe uitgelê is.'

Kara vind dit belangrik om oor die lewe en haar geloof na te dink en vas te stel of sy nog besig is met dit wat werklik belangrik is in die lewe. Die Heilige Gees speel 'n groot rol in haar lewe. Sy stel dit soos volg: 'As die Heilige Gees my nie van iets oortuig nie, dan glo ek dit nie.'

Kara wil haar kinders op die huwelik en verhoudings voorberei. Sy beklemtoon liefde in die verhouding en dat mense nie moet probeer om mekaar te verander nie. Sy wil haar kinders leer dat die huis 'n veilige plek behoort te wees waar daar liefde is, waar mense bymekaarkom, waar dit gemaklik is en mense hulleself kan wees. Kara meen dat vroue sterk mag wees en regte het. Vir haar is 'n vrou se hooftaak om 'die liefde in die prentjie te hou'.

\section{Prosessering}

Lewenstorienavorsing verkies die term prosesseer bo analiseer, omdat dit nie op statistiek en die rekenaarmatige analise van data gebaseer is nie (Cole \& Knowles 2001:99-100). In lewenstorienavorsing gaan dit oor 'n proses waarin die navorser en navorsingsvennoot saam oor die lewensstorie en konteks reflekteer. Cole en Knowles (2001) beskryf die proses soos volg:

We do so not by taking information and slicing it into discrete bits and storing the pieces in separate containers, but by trying to understand, in a holistic way, the connectedness and interrelatedness of human experience within complex social systems. (bl. 101)

Die refleksie op die vroue se narratiewe fokus op sekere temas soos die volgende: hulle ervaring binne die huwelik; die historiese erfenis wat aan hulle oorgedra is; en wat hulle deur die kerk en samelewing voorgeskryf is wat van hulle verwag word binne die huwelik; hulle verhouding met God; en hoe hulle hulleself binne hulle konteks verstaan.

\section{Ruda}

Ruda vind dit moeilik om haar in die huwelik van die voorgeskrewe geslagsrol los te maak, naamlik dat die man die broodwinner moet wees en die vrou vir alle huishoudelike en kinderversorgingstake verantwoordelik is. Sy aanvaar dat dit is wat die kerk en die samelewing leer en voorskryf (kyk NHKA Diensboek 2007:77-83). Die gevolg is vir haar 'n innerlike worsteling, veral veroorsaak deur die eise wat veranderde omstandighede aan haar stel. 
Omstandighede het genoodsaak dat sy buitenshuis werk sodat sy haar kinders kan onderhou. Die sosialisering en kondisionering deur haar ouers, die samelewing en die huweliksbevestingsformulier van haar kerk, dat sy naamlik aan haar man onderdanig moet wees en die rol van vrou en moeder moet vervul, was egter in konflik daarmee. Die besluit om nie langer in 'n huweliksverhouding te bly waar sy fisies en emosioneel vernietig word nie, het tot verwerping deur haar geloofsgemeenskap en haar ouers gelei. Hulle het gevoel dat sy nie genoeg gedoen het om die huwelik in stand te hou nie. Ballou en Gabalac (1985:81-97) noem dit die retribution van die samelewing wanneer vroue hulle nie hou aan gedrag wat 'gepas is vir ' $\mathrm{n}$ vrou' nie. Ruda het selfs in haar tweede huwelik nie daarin geslaag om van die geslagsrolle waartoe sy gekondisioneer was, bevry te word nie. Sy vind dit moeilik om 'n eie beroep te beoefen en huiwer om werksgeleenthede aan te gryp. Sy stel haarself steeds ondergeskik aan die belange van haar man en maak opofferings sodat hy bevorder kan word. Telkens lei dit tot bepaalde nadele van haarself en haar kinders in die omstandighede waarin hulle hulself bevind.

Wanneer Ruda se lewensstorie in gesprek gebring word met die historiese erfenis van Afrikaanssprekende vroue ten opsigte van hulle plek in die samelewing, hulle posisie in die kerk en hulle rol in die huwelik, word dit duidelik dat sy, soos geslagte vroue voor haar, nie vry van die patriargale hegemonie van die Afrikanerkultuur kon funksioneer nie. Sy het die boodskap geïnternaliseer dat 'n vrou se menswaardigheid deur haar verbintenis aan 'n man bepaal word en dat haar rol in daardie verbintenis is om die ondergeskikte te wees wat haar man se belange, werk en ambisies voor haar eie stel. Die effek van hierdie geïnternaliseerde boodskap is dat dit negatief op haar inwerk. Dit verhinder haar om outentiek mens en vrou te wees (kyk Dreyer 1998:6). Sy ly aan skuldgevoelens omdat sy meen dat sy nie voldoen waaraan God by monde van die samelewing en die kerk van haar as vrou vra nie. Daar is by haar die versugting om van hierdie gevoel vry te wees, naamlik dat sy as vrou nie is en doen wat sy veronderstel is om te wees en te doen nie.

\section{Lulu}

In Lulu se ouerhuis is onderskeid getref tussen 'seunswerk' en 'meisieswerk'. Weens praktiese oorwegings is sy en haar susters genoop om sogenaamde seunswerk te doen. Met die afsterwe van haar pa toe sy 16 jaar oud was, moes sy gaan werk om haar ma met die versorging van haar susters en broers te help. Hierdie omstandighede het daartoe gelei dat sy anders as die norm van die samelewing in daardie tyd moes optree, naamlik dat jong vroue so gou moontlik trou en met 'n gesin begin (vgl. Barnard-Weiss 1999:56). Haar verhouding met haar man is ook anders as wat van 'n plattelandse milieu verwag kan word, wat dikwels meer patriargaal in die stede was. Sy en haar man het verantwoordelikhede op die plaas gedeel en saamgewerk om alles gedoen te kry. Hulle verhouding was dié van vriend en vriendin wat alles kon bespreek en alles kon deel. Sy het wel as vrou die tradisionele rol vervul om vir kinders kategese aan te bied. Dit blyk dat sy in haar huwelik die tradisionele onderdanige rol van die vrou oorstyg het en sy en haar man as vennote kon funksioneer. Hulle kon ook besluitneming oor die gesin, kinders en die toekoms deel. Sy beleef God as die versorgende God wat gebede verhoor en uitkoms gee in die nood wat hulle beleef het. Na die afsterwe van haar man, gaan sy met die boerdery vir 'n paar jaar voort. Sy is oortuig dat ' $n$ vrou 'n mens in eie reg is.

Lulu se verhaal klink anders as dié van Ruda. Die rede daarvoor is waarskynlik omdat sy ' $n$ ander ervaring in haar gesin van oorsprong gehad het. Haar ma moes self werk om die gesin te versorg. Dit is ook anders omdat Lulu se man nie met die dinge wat hy van haar as vrou verwag het, die samelewingsdiskoers gehandhaaf het nie. Dit is anders omdat Lulu nie bereid was om die gevoel van eiewaarde wat sy ontwikkel het as gevolg van die feit dat sy van jongs af moes werk en suksesvol saam met haar man hulle plase bestuur het, prys te gee en te konformeer aan die rolle wat deur die kerk en die samelewing voorgeskryf is nie. Haar verhaal bevestig dat, waar tradisie met vroue se ervaring gekonfronteer word, verandering moontlik is (vlg. Graham 2002:175). Lulu se huwelik is 'n getuienis daarvan dat twee volwassenes as gelyke vennote in 'n huweliksverhouding kan saamleef en saamwerk sonder dat die een onderdanig, ondergeskik of minderwaardig aan die ander hoef te wees.

\section{Johanna}

Johanna se ouerhuis, konteks en agtergrond was patriargaal en tradisioneel. Haar pa was die finansiële versorger van die gesin en haar ma moes die huishouding behartig. Haar man se ma het buitenshuis gewerk en geld vir die gesin ingebring. Ten spyte hiervan en van die feit dat Johanna 'n gegradueerde beroepsvrou was, was die rolle in haar huwelik steeds tradisioneel (kyk Peacock 1993:74-75). Sy is steeds vir die huishouding en kinderversorgingstake verantwoordelik. Die feit dat vroue-arbeid lank minder werd geag is as dié van mans en dat vroue daarom swakker betaal kon word, is in hierdie verhaal gedemonstreer (kyk Neuger 2001:16-17). Selfs met 'n universiteitsgraad is die vrou aanvanklik op 'n laer vlak as die man sonder kwalifikasies aangestel. Dit het intussen verander. Johanna blameer haarself en haar buitenshuise werk vir die mislukking van haar huwelik. Hierdie beskuldiging is dikwels in die verlede voor werkende vroue se deur gelê, naamlik dat die toename van vroue in die arbeidsmark verantwoordelik is vir die toename in die egskeidingsyfer (kyk Raath [1959] 1960:46; vgl Louw 1983:14; Neuger 2001:16-19). Ook die idee dat vroue alleen verantwoordelik is om huweliksverhoudings in stand te hou (die man gelukkig te maak, of te hou), kom in hierdie verhaal na vore (McGoldrick 1989:200-201; kyk Browning 2004:127-137).

Johanna blameer die duiwel vir haar mislukte huwelik, hoewel haar man 'n verhouding met 'n ander vrou gehad het. Johanna is van mening dat die duiwel haar gelukkige huwelik kom vernietig het. Hierdie manier van omgaan met 
haar werklikheid weerspieël 'n oorblyfsel van die piëtistiese spiritualiteit van die blanke Afrikaanssprekende vroue in die agtiende en negentiende eeu (kyk Landman 1994:42-44). Skuld word na iemand of iets anders verplaas, sodat sy nie die ware toedrag van sake hoef te konfronteer nie (Cromwell \& Thurman 2003:541; vgl. Neuger 2001:14-15). So beskerm sy selfs in hierdie omstandighede haar man. Sy meen ook dat God negatiewe dinge oor haar bring sodat sy daaruit kan leer. Sy beskou dit as sonde om te skei en dat sy teenoor God oortree het deur van haar man te skei op grond van sy owerspel. Die beskerming van die man en die verwronge toekenning van skuld is die gevolg daarvan dat vroue deur samelewingsdiskoerse alleen vir die instandhouding van die huweliksverhouding verantwoordelik gehou word (kyk Neuger 2001:19). Johanna se biblisistiese Skrifhantering blyk daaruit dat sy as geskeide vrou 'op grond van die Bybel' nie weer mag trou nie.

\section{Annetjie}

Annetjie se ma het haar geleer dat vroue vir hulleself moet kan sorg en nie van 'n man afhanklik moet wees nie. Hierdie ma het haar dogter dus anders geleer as hoe sy self geleer is. Sy self en vroue van haar era was volledig van die man afhanklik. Hoewel Annetjie in haar huwelik nie finansieel van haar man afhanklik is nie, vervul sy steeds die tradisionele vrouerol (kyk NHKA Diensboek 2007:79). Hoewel sy heeltyds buitenshuis werk en dus teenstrydig met hierdie roltoekenning 'n mede-broodwinner in die gesin is, bly sy alleen vir alle huishoudelike en kinderversorgingstake verantwoordelik. Haar man verwag enersyds dat sy onafhanklik sal wees en sy tradisioneel manlike broodwinnersrol met hom sal deel, maar andersyds beskou hy dit nie as nodig (of regverdig) dat hy dan ook haar tradisionele take met haar hoef te deel nie. Hy bly volledig onbetrokke by die huishouding. Hier geld die dubbele standaarde wat dikwels in kerklike en samelewingsdiskoerse aan die orde is wanneer dit by vroue kom. Annetjie skryf haar man se onbetrokkenheid by hulle huishouding toe aan die feit dat dit die voorbeeld is wat hy by sy pa gesien het. Net soos met Johanna is hier ook sprake van die meganisme wat tradisionele vroue dikwels gebruik, naamlik om iets of iemand anders te blameer sodat die eie eggenoot se gedrag daarmee verskoon kan word. Annetjie toon steeds tekens van die diepgewortelde en gevestigde persepsies oor geslagsrolle wat eeue lank aan vroue en mans oorgedra is. Sy aanvaar steeds dat daar voorgeskrewe rolle is wat haar man en sy in die huwelik behoort te vervul. Sy volg die pad wat familieterapeute McGoldrick, Anderson en Walsh (1989:8) uitgewys het, naamlik dat jong vroue vir wie 'n goeie werk en opleiding belangrik is, tog na die tradisionele rolle terugkeer sodra die eerste kind gebore word.

Annetjie se Godsbeeld verskil egter van dié van Johanna. Johanna glo dat God slegte dinge met mense laat gebeur, terwyl God nie vir Annetjie die outeur van die kwaad in die lewe van mense is nie. Sy glo dat goed en sleg deel van die lewe is en dat geloof en vertroue op God 'n mens help om dit te deurstaan.

\section{Kara}

Kara word groot in 'n huis waar die huweliksverhouding tussen haar ouers moeilik was. Haar ma se raad oor die huwelik was ook nie positief nie en weerspieël iets van haar eie ervaring in die huwelik, naamlik dat dit iets is wat moeite verg om in stand te hou. Kara het nie haar ma se boodskap geïnternaliseer nie, maar het self besluit hoe sy die huwelik sien en hoe sy met haar man wil saamleef. Sy het nie toegelaat dat die negatiewe ervaring van haar ma, ook haar ervaring word nie. Sy het wel aan die begin van haar huwelik 'n 'huis-huis prentjie' gehad wat sy oorsprong in die voorgeskrewe geslagsrolle van die samelewing en die kerk het (kyk Walker 1990:25). Omstandighede tydens die eerste jare van hulle huwelik en die dinamiek van haar huweliksverhouding het daartoe bygedra dat sy kon insien dat dit nie op die lang duur vir haar en hulle huwelik gaan werk om aan tradisionele idees oor die huwelik vas te klou nie.

Kara en haar man kon vrylik in hulle huwelik kommunikeer en as gelyke genote in sowel die huwelik as die besigheid funksioneer. Dit kan deels toegeskryf word aan die voorbeeld wat Kara se man in sy eie gesin van oorsprong gehad het. Die meesternarratief (kyk Lyotard [1979] 1984:18-37; kyk Boeve 2014) oor die huwelik in sy ouerhuis was anders as die tradisionele. Dit het tot die alternatiewe interaksie in sy eie huwelik bygedra. Kara se ervaring in haar gesin van oorsprong en haar interaksie met haar man het haar van die tradisionele rolverwagting bevry wat sy aanvanklik van die huwelik gehad het, naamlik dat haar man die broodwinner moes wees en sy die tuisteskepper. Dit het tot die siening ontwikkel dat hulle mekaar aanvul en ondersteun en dat elkeen sal doen wat nodig is, ongeag die voorgeskrewe geslagsrolle. Die verhaal bevestig dat ervaring daartoe kan bydra dat ' $n$ ander stem gehoor word as die tradisionele en ander insigte ten opsigte van die rolle en verwagtings in die huwelik kan ontwikkel. Hierdie ander stem kan positiewe verandering ten opsigte van die huwelik meebring (vgl. Graham 2002:175) en vroue in staat stel om ook in die huwelik outentiek te lewe.

Hoewel Kara en Lulu uit verskillende eras kom, slaag hulle in sekere opsigte daarin om weg te beweeg van die eeue oue kondisionering van hoe vroue in die huwelik behoort op te tree en wat in die blanke Afrikaanssprekende kultuur in Suid-Afrika die dominante diskoers was en steeds is. Hulle reël hulle huwelik soos wat dit in hulle omstandighede en konteks beter pas en nie noodwendig volgens hoe die kerk en die samelewing voorgeskryf het dat dit moet wees nie.

Kara beleef God as teenwoordig by alles wat met haar in haar lewe gebeur. God laat, volgens haar, nie slegte dinge met mense gebeur nie, maar laat toe dat dinge op 'n mens se pad kom. Dit is deel van die lewe, maar God help 'n mens daardeur en daarin. Die teenwoordigheid van die Heilige Gees is belangrik in haar geloof. Sy wil na die Gees luister en doen wat God vra. 


\section{Resultate}

Uit die lewensstorienavorsing se onderhoude met gespreksgenote blyk dit dat die rolle wat die samelewing en die kerk aan vroue voorgehou het ' $n$ effek op hulle manier van dink en leef in die huwelik het, asook op die manier waarop hulle hul rolle as vrou in die huwelik vervul. Twee van die gespreksgenote kon daarin slaag om hulle huwelike anders in te rig as wat tradisioneel aan hulle voorgehou is, deur 'n meer gelyke rolverdeling tussen hulle en hulle mans. Outentieke identiteitsvorming, 'n outentieke lewe as mens in die samelewing, en 'n outentieke lewe voor God skyn nie vir die vroue deur die kerklike diskoers oor die vrou en die huwelik bevorder te word soos wat dit onder andere uit die huweliksformulier blyk waaraan hulle blootgestel is nie. Dit bied nie aan vroue die ruimte, of moedig hulle geensins aan om in hulle spiritualiteit tot selfstandige, denkende en handelende persone te ontluik nie. Indien die ervaring van vroue soos uit hierdie lewens- en geloofstories geblyk het, ernstig geneem word, word dit duidelik dat transformasie nodig is, sowel in die praktyk van die geloofsgemeenskap van die NHKA as in die praktyk van die huwelike van mense wat hulle huwelikslewe in God se teenwoordigheid wil lei. Die huwelik en hulle lewe coram Deo behoort vir vroue 'n lewegewende en lewensverrykende ervaring te wees. Sommige van hierdie narratiewe was egter verhale van inperking, onreg, minderwaardigheid, frustrasie en 'n lig wat volgens die voorskrifte van die kerk en die samelewing onder die maatemmer verberg moes word. Die ervaring van hierdie vroue asook die veranderde hedendaagse konteks vra om transformasie van die diskoerse en die praktyk van die huwelik sodat daar vir alle mense, ook vir vroue, ruimte sal wees om outentiek te lewe.

\section{Erkenning \\ Mededingende belange}

Die outeur verklaar dat sy geen finansiële of persoonlike verhouding(s) het wat haar op 'n voordelige of nadelige wyse in die skryf van die artikel beïnvloed het nie.

\section{Literatuurverwysings}

Ackermann, D., Draper, J.A. \& Mashinini, E., 1991, Women hold up half the sky, Cluster, Pietermaritzburg.

Ballou, M. \& Gabalac, N.W., 1985, A feminist position on mental health, Thomas, Springfield, MA.

Barnard-Weiss, M., 1999, 'Die vrou in die Nederduitsch Hervormde Kerk van Afrika: Haar beeld en kerklike rol, 1940-1985', DPhil-proefskrif, Dept. Geskiedenis, Universiteit van Pretoria.
Bertaux-Wiame, I., 1979, 'The life history approach to the study of internal migration', Oral History 7(1), 26-32.

Boeve, V., 2014, Lyotard and theology, Clark, Londen. (Philosophy and Theology).

Browning, D., 2004, 'Reflections on the debate', in D. Blankenhorn, D. Browning \& M. Stewart van Leeuwen (eds.), Does Christianity teach male headship? The equal-regard marriage and its critics, pp. 126-138, Eerdmans, Grand Rapids, MI.

Cohen, J.L., 1995, 'Critical social theory and feminist critiques', in J. Meehan (ed.), Feminists read Habermas: Gendering the subject discourse, pp. 57-90, Routledge, New York, MI.

Cole, A.L. \& Knowles, J.G., 2001, Lives in context: The art of life history research, Alta Mira, New York, NY.

Cromwell, P. \& Thurman, Q., 2003, 'The devil made me do it: Use of neutralizations by shoplifters', Deviant Behavior 24(6), 535-550. http://dx.doi. org/10.1080/713840271

Dhunpath, R., 2000, 'Life history methodology: “Narradigm” regained', International Journal of Qualitative Studies in Education 13(5), 543-551. http://dx.doi. org/10.1080/09518390050156459

Dreyer, Y., 1998, 'Pastorale interaksie met vroue: 'n Prakties-teologiese begronding', DD-proefskrif, Fakulteit Teologie, Universiteit van Pretoria.

Geiger, S.N.G., 1986, 'Women's life histories: Method and content', Signs 11(2), 334-351. http://dx.doi.org/10.1086/494227

Goodson, I.F., 1992, Studying teachers' lives, Routledge, London. http://dx.doi. org/10.4324/9780203415177

Graham, E.L., 2002, Transforming practice: Pastoral theology in an age of uncertainty, 2nd edn., Wipf \& Stock, Eugene, OR.

Landman, C., 1994, The piety of Afrikaans women: Diaries of guilt, University of South Africa, Pretoria.

Lawrence-Lightfoot, S., 1994, I've known rivers: Lives of loss and liberation, AddisonWesley, New York, NY.

Louw, D.J., 1983, Die volwasse huwelik, Butterworths, Durban.

Lyotard, J-F., [1979] 1984, The postmodern condition: A report on knowledge, 2nd edn., transl. G. Bennington \& B. Massumi, University of Minnesota Press, Minneapolis, MN.

Mandelbaum, D.G., 1973, 'The study of life history: Gandhi', Current Anthropology 14(3), 177-196. http://dx.doi.org/10.1086/201318

McGoldrick, M., 1989, 'Women through the family life cycle', in M. McGoldrick, C.M. Anderson \& F. Walsh (eds.), Women in families: A framework for family therapy, pp. 200-226, Norton, New York, NY.

McGoldrick, M., Anderson, C.M. \& Walsh, F., 1989, 'Woman in families and in family therapy', in M. McGoldrick, C.M. Anderson \& F. Walsh (eds.), Women in families, a framework for family therapy, pp. 3-15, Norton, New York, NY.

Meehan, J. (ed.), 1995, Feminists read Habermas: Gendering the subject discourse, Routledge, New York, NY

Meehan, J., 2000, 'Feminism and Habermas' discourse ethics', Philosophy and Social Criticism 26(3), 39-52. http://dx.doi.org/10.1177/019145370002600302

Middeltone, S., 1992, 'Developing a radical pedagogy: Autobiography of a New Zealand sociologist ofwomen'seducation', in I.F.Goodson(ed.),Studyingteachers, pp. 18-50, Routledge, Londen. http://dx.doi.org/10.4324/9780203415177_chapter_2

Nederduitsch Hervormde Kerk van Afrika, 2007, Diensboek, pp. 7-92, Sentik, Pretoria.

Neuger, C.C., 2001, Counseling women: A narrative, pastoral approach. Fortress, Minneapolis, MN.

Peacock, A., 1993, 'Take my intellect, and use', in E.L. Graham \& M.J. Halsey (eds.), Life cycles: Women in pastoral care, pp. 71-79, SPCK, Londen.

Polkinghorne, D.E., 1988, Narrative knowing and the human sciences, New York Press, New York, NY.

Raath, J.M., [1959] 1960, 'Die toetrede van die vrou tot die arbeidsmark', in NHSV Jaarboek 1959-1960, pp. 40-51.

Schulenburg, A., 1993, Feministische Spiritualität: Exodus in eine befreiende Kirche?, Kohlhammer, Stuttgart.

Schüssler Fiorenza, E., 2006, 'A critical feminist emancipative reading', in A. Choi Hee $\&$ K. Pfisterer Darr (eds.), Engaging the Bible: Critical readings from contemporary women, pp. 81-104, Fortress, Minneapolis, MN

Sonne, E.M., 1993, Prodigal daughter: Coming home, Exlibris, Bloomington, IN.

Walker, C. (ed.), 1990, Women and gender in Southern Africa to 1945, David Philip, Claremont. 